\title{
Pengaruh Kualitas Penerapan Good Corporate Governance (GCG) Terhadap Tingkat Pengembalian dan Risiko Pembiayaan Bank Syariah di Indonesia
}

Fathan Budiman

Program Pascasarjana IAIN Sunan Kalijaga Yogyakarta

Email : fathan_budiman@yahoo.com

\begin{abstract}
The emergence of concept of Good Corporate Governance (GCG) is based on agency theory that expects the disclosure of information so that conflicts of interest among the principal agent can be minimized. Conflicts of interest can occur in any company including Islamic banking. This situation is recognized by Bank Indonesia, which then requires the application of the principles of GCG in Bank Indonesia regulations at PBI No. 8/4 / PBI / 2006. The purpose of this study was to describe the quality of the implementation of Good Corporate Governance of Islamic Banking in Indonesia and to analyze their effects on the financial performance and operational efficiency. Financial performance is measured by earnings (ROA), and liquidity (FDR). The object of this study is Islamic banking companies that issue an annual report and a report on the implementation of Good Corporate Governance period of 2013-2015 in accordance with Circular Letter No. BI. 12/13/BPbs on April 30, 2010. Types of data used are secondary data from a composite ranking score of Good Corporate Governance as measured by 11 indicators for BUS and 5 indicators for UUS, and ratio ROA, and NPF. The variables were analyzed using simple linear regression analysis. The results showed that the quality of the implementation of Good Corporate Governance (GCG) has negative effect on the return of Islamic banks measured by profitability (ROA) and a significant negative effect on the risk financing Islamic bank as measured by asset quality (NPF).
\end{abstract}

Keywords: Good Corporate Governance, financial performance, operational efficiency. 


\begin{abstract}
Abstrak
Munculnya Konsep Good Corporate Governance (GCG) didasarkan pada agency theory yang mengharapkan adanya keterbukaan informasi sehingga konflik kepentingan antara agen dengan principal dapat diminimalisir. Konflik kepentingan dapat terjadi pada setiap perusahaan termasuk perbankan syariah. Keadaan ini disadari oleh Bank Indonesia yang kemudian mewajibkan penerapan prinsip GCG dalam peraturan Bank Indonesia yaitu PBI No. 8/4/ PBI/2006. Tujuan penelitian ini adalah menguji bagaimana pengaruh GCG terhadap kinerja keuangan Bank Umum Syariah.Tujuan dari penelitian ini untuk menjelaskan pengaruh kualitas pelaksanaan Good Corporate Governance Bank Syariah di Indonesia terhadap tingkat pengembalian dan risiko pembiayaan. Tingkat pengembalian diukur dengan return on assets (ROA) dan risiko pembiayaan dengan non performing financing (NPF). Objek penelitian ini adalah perusahaan perbankan syariah yang mengeluarkan laporan tahunan dan laporan pelaksanaan Good Corporate Governance periode 2013-2015 yang sesuai dengan Surat Edaran BI No. 12/13/BPbs pada tanggal 30 April 2010. Jenis data yang digunakan adalah data sekunder berupa nilai pemeringkatan komposit Good Corporate Governance yang diukur dengan 11 indikator untuk BUS dan 5 indikator untuk UUS, serta rasio ROA dan NPF. Variabel penelitian dianalisis menggunakan analisis regresi linear sederhana. Hasil penelitian menunjukkan bahwa kualitas pelaksanaan Good Corporate Governance (GCG) berpengaruh negatif terhadap tingkat pengembalian bank syariah yang diukur dengan rentabilitas (ROA) dan berpengaruh negatif signifikan terhadap risiko pembiayaan bank syariah yang diukur dengan kualitas asset (NPF).
\end{abstract}

Kata Kunci: Good Corporate Governance, tingkat pengembalian, risiko pembiayaan

\title{
Pendahuluan
}

Perkembangan industri syariah telah mengalami pertumbuhan yang cukup menggembirakan. Selama satu tahun terakhir (2015) total aset atau volume usaha perbankan syariah sebesar Rp.199,72 triliun (34\%), tahun 2014 sebesar Rp.187,2 triliun (48,6\%), dan tahun 2013 sebesar Rp. 97 triliun (47,56\%) (BI, 2016). Pangsa pasar (market share) perbankan syariah pada tahun 2015 sebesar 4,32\%, tahun 2014 sebesar 3,6\%, dan tahun 2013 sebesar $3,3 \%$ dari total aset industri perbankan (Republika, 2016) 
Jumlah bank yang melakukan kegiatan usaha berdasarkan prinsip syariah pada tahun 2015 bertambah seiring dengan beroperasinya sejumlah bank syariah baru. Jumlah BUS dan UUS tidak bertambah dari tahun sebelumnya yaitu tetap sebanyak 11 BUS dan 24 UUS. Sementara itu jumlah BPRS bertambah dari 155 BPRS menjadi 158 BPRS (BI, 2016)

Pesatnya pertumbuhan tersebut mutlak harus diberengi dengan penerapan tata kelola perusahaan yang baik, sehingga lembaga keuangan syariah tidak hanya berlabel syariah tetapi juga benar-benar bersikap profesional sehingga dapat bersaing dengan lembaga keuangan konvensional. Prinsipprinsip GCG merupakan intisari dari nilai-nilai syariah itu sendiri. GCG baru disadari beberapa dasawarsa belakangan ini. Padahal ajaran Islam telah mengajarkannya sejak masa Rasulullah SAW, sekitar 14 abad tahun yang silam.

Penerapan prinsip GCG dalam dunia perbankan Indonesia merupakan tuntutan agar perusahaan-perusahaan yang ada jangan sampai terlindas oleh persaingan global yang semakin keras. Prinsip-prinsip GCG pada dasarnya memiliki tujuan untuk memberikan kemajuan terhadap kinerja bank syariah, khususnya peningkatan tingkat pengembalian (laba) dan penekanan risiko pembiayaan bank syariah.

Paper ini bertujuan untuk melakukan analisis pengaruh kualitas penerapan GCG terhadap tingkat pengembalian dan risiko pembiayaan bank syariah di Indonesia.

\section{GCG pada Perbankan Syariah}

Penerapan prinsip-prinsip GCG menjadi suatu keharusan bagi sebuah institusi, termasuk di dalamnya institusi bank syariah. Hal ini lebih ditujukan kepada adanya tanggung jawab publik (public accountability) berkaitan dengan kegiatan operasional bank yang diharapkan benarbenar mematuhi ketentuan-ketentuan yang telah digariskan dalam hukum positif. Di samping itu juga berkaitan dengan kepatuhan bank syariah terhadap prinsip-prinsip syariah sebagaimana yang telah digariskan dalam al-Quran, Hadis, dan Ijmak para ulama.

Penerapankan Good Corporate Governance yang efektif di lembaga keuangan syariah merupakan keharusan. GCG adalah pilar penting untuk 
mewujudkan bank syariah yang unggul dan tangguh. Apalagi dalam operasionalnya bank syariah menggunakan konsep risk sharing.

Keberhasilan penerapan GCG untuk kemajuan bank syariah, mesti memerlukan sarana pendukung. Diantara sarana pendukung corporate governance yang terpenting adalah kontrol internal, manajemen resiko, tranparansi, akuntansi dan disclosure pembiayaan, pemurnian dan audit syariah, regulasi dan pengawasan yang prudent.

Pelaksanaan good corporate governance pada industri perbankan syariah berlandaskan pada lima prinsip dasar. Pertama, transparansi (transparency), yaitu keterbukaan dalam mengemukakan informasi yang material dan relevan serta keterbukaan dalam proses pengambilan keputusan. Kedua, akuntabilitas (accountability), yaitu kejelasan fungsi dan paksanaan petanggungjawaban organ bank sehingga pengelolaanya berjalan secara efektif. Ketiga, pertanggung jawaban (responsibility), yaitu kesesuaian pengelola bank dan peraturan perundang-undangan yang berlaku dan prinsiprinsip pengelolaan bank yang sehat. Keempat, profesional (professional), yaitu memiliki kompetensi, mampu bentindak obyektif dan bebas dari pengaruh/tekanan dari pihak manapun (independen) serta memiliki komitmen yang tinggi untuk mengembangkan bank syariah. Kelima, kewajaran (fairness), yaitu keadilan dan kesetaraan dalam memenuhi hak-hak stakeholders berdasarkan perjanjian peraturan perundang-undangan yang berlaku.

Dalam rangka menerapkan kelima prinsip dasar tersebut, bank wajib berpedoman pada berbagai ketentuan dan persyaratan yang terkait dalam pelaksanaan Good Corvorate Governance. Selain itu dalam pelaksanaan Good Corporate Governance pada perbankan syariah juga harus memenuhi prinsip syariah (sharia compliance). Ketidak sesuaian tata kelola bank dengan prinsip syariah akan berpotensi menimbulkan berbagai risiko terutama risiko reputasi bagi industri perbankan syariah.

Pelaksaaan Good Corporate Governance perbankan syariah tidak hanya dimaksudkan untuk memperoleh pengelolaan bank yang sesuai dengan lima prinsip dasar dan sesuai dengan prinsip syariah, akan tetapi juga di tujukan untuk kepentingan yang lebih luas. Kepetingan tersebut antara lain untuk melindungi kepentingan stakeholders dan meningkatkan kepatuhan 
terhadap peraturan perundang-undangan yang berlaku serta nilai-nilai etika yang berlaku secara umum pada industri perbankan syariah.

\section{Teori dan Telaah Penelitian Sebelumnya}

Bank selalu berkaitan dengan masalah keuangan, yaitu menghimpun dana, menyalurkan dana, dan memberikan jasa bank lainnya. Dengan demikian bank sebagai suatu badan berfungsi sebagai perantara keuangan (financial intermediary) dari dua pihak yang kelebihan dana (surplus unit) dan pihak yang kekurangan dana (deficit unit).

Istilah "corporate governance" (tata kelola perusahaan) berasal dari suatu analogi antara pemerintahan suatu negara atau kota dengan pemerintahan dalam suatu perusahaan (Zarkasyi, 2008). Definisi Cadbury mengatakan bahwa Good Corporate Governance adalah mengarahkan dan mengendalikan perusahaan agar tercapai keseimbangan antara kekuatan dan kewenangan perusahaan. Dari berbagai definisi, dapat disimpulkan bahwa GCG adalah suatu sistem yang mengatur dan mengendalikan perusahaan untuk menciptakan nilai tambah (value added) untuk semua stakeholdersnya, mengarahkan dan mengendalikan perusahaan agar tercapai keseimbangan antara kekuatan dan kewenangan perusahaan.

Hasil penelitian Anggraeni (2010) tentang hubungan penerapan GCG dan kinerja keuangan perusahaan pada perbankan syariah menunjukan penerapan GCG berpengaruh signifikan terhadap kinerja perusahaan yang diukur dengan tingkat pengembalian asset. Penelitian Eirene (2010) menunjukkan bahwa penerapan GCG berpengaruh positif terhadap tingkat pengembalian ekuitas perusahaan. Kedua Hasil penelitian diatas diperkuat oleh Bhagat dan Bolton (2008) yang melakukan pengujian secara komprehensif tentang pengaruh tata kelola perusahaan terhaadap tingkat pengembalian atas asset, pengujian yang dilakukan dengan menggunakan tujuh alat ukur yang berbeda mengungkapkan bahwa tata kelola perusahaan yang baik berpengaruh positif terhadap operating performances/return on assets. Berlandaskan hasil penelitian diatas, maka hipotesis pada penelitian ini adalah: $\mathrm{H}_{1}$ : Kualitas penerapan GCG $(\mathrm{X})$ berpengaruh terhadap tingkat pengembalian $\left(\mathrm{Y}_{1}\right)$. 
Nagoro (2008) dalam penelitiannya menemukan penerapan prinsip GCG berpengaruh terhadap pengurangan NPL. Claessens dan Fan (2002) menemukan hubungan antara penerapan GCG dengan pengurangan risiko keuangan. Menurut Budiarti (2010) terciptanya GCG dalam organisasi merupakan salah satu penjabaran dari terlaksananya mekanisme pengelolaan risiko organisasi melalui sistem yang dirancang dalam rangka mengidentifikasi dan menganalisa risiko yang mungkin terjadi. Selain itu, ditetapkannya at uran BI mengenai penerapan GCG sendiri ditujukan untuk mengurangi risiko. Maka Berdasarkan landasan teori dan rerangka konseptual diatas, hipotesis yang akan diuji pada penelitian ini adalah:

$\mathrm{H}_{2}$ : Kualitas penerapan GCG $(\mathrm{X})$ berpengaruh terhadap risiko pembiayaan $\left(\mathrm{Y}_{2}\right)$.

\section{Metodologi Penelitian}

\section{Data dan Sumber Data}

Penelitian ini menggunakan data sekunder yaitu berupa laporan Good Corporate Governance Bank Syariah periode 2013-2015, laporan keuangan tahunan bank syariah periode 2013-2015, dan data statistik Bank Indonesia. Bank syariah yang dijadikan obyek penelitian dapat berbentuk Bank Umum Syariah (BUS), Unit Usaha Syariah (UUS). Data bersumber dari website resmi Bank Syariah dan Bank Indonesia dengan teknik pengumpulan dokumentasi.

Untuk kepentingan analisis data, obyek dipilih dengan metode purposive sampling dengan kriteria: 1) Menerbitkan laporan keuangan tahunan dan laporan GCG periode 2013-2015; dan 2) Isi laporan GCG periode 2013-2015 yang dipublikasikan paling kurang meliputi hal-hal yang wajib diungkapkan oleh BUS dan UUS sesuai pasal 62 PBI No. 11 Tahun 2009.

Variabel bebas dalam penelitian ini adalah kualitas penerapan Good Corporate Governance. Diukur dengan nilai komposit peringkat kualitas penerapan GCG bank berdasarkan Surat Edaran BI No. 12/13/DPbS Tahun 2010 . 
Tabel 1 Nilai Pemeringkatan Komposit

\begin{tabular}{ll}
\hline Tingkat/Nilai Pemeringkatan Komposit & Predikat Komposit \\
\hline nilai komposit $<1,5$ & Sangat Baik \\
$1,5 \leq$ nilai komposit $<2,5$ & Baik \\
$2,5 \leq$ nilai komposit $<3,5$ & Cukup Baik \\
$3,5 \leq$ nilai komposit $<4$ & Kurang Baik \\
$4,5 \leq$ nilai komposit $<5$ & Tidak Baik \\
\hline
\end{tabular}

Sumber : Surat Edaran BI No. 12/13/DPbS Tahun 2010

\section{Variabel Terikat (dependent)}

\section{Tingkat Pengembalian}

Rasio yang digunakan dalam penelitian ini adalah Return on Assets (ROA). Return on Assets menunjukkan kemampuan manajemen bank dalam menghasilkan laba dari pengelolaan asset yang dimiliki. ROA merupakan rasio yang juga digunakan untuk mengukur kemampuan manajemen bank dalam memperoleh laba bank syariah.

Tingkat profitabilitas bank syariah di Indonesia yang paling tepat diukur dari rasio laba terhadap asset (ROA), baik untuk kategori bank yang full fledge maupun untuk kategori Unit Usaha Syariah.

ROA digunakan untuk mengukur profitabilitas bank karena Bank Indonesia sebagai pembina dan pengawas perbankan lebih mengutamakan nilai profitabilitas suatu bank, diukur dengan asset yang dananya sebagian besar dari dana simpanan masyarakat. Semakin besar ROA suatu bank, semakin besar pula tingkat keuntungan yang dicapai bank, dan semakin baik pula posisi bank dari segi penggunaan asset. ROA dapat diukur dengan persamaan sebagai berikut:

$$
\text { ROA }=\text { Laba Sebelum Pajak x 100\% }
$$

Total Asset

\section{Risiko Pembiayaan}

Risiko pembiayaan adalah risiko kerugian sehubungan dengan pihak peminjam tidak dapat dan atau tidak mau memenuhi kewajiban untuk membayar kembali dana yang dipinjamkannya secara penuh pada saat jatuh tempo. Risiko pembiayaan dalam penelitian ini diproksikan dengan NPF. 
NPF adalah pembiayaan bermasalah/pembiayaan non produktif dihitung dengan menjumlahkan seluruh pembiayaan yang tergolong dalam klasifikasi substandard, meragukan dan macet. NPFs pada penelitian ini diukur dengan NPF dengan persamaan tersebut sebagai berikut:

$\mathrm{NPF}=$ Total Pembiayaan Bermasalah $\times 100 \%$

Total Pembiayaan

\section{Metode Analisis Data}

\section{Uji Normalitas dan Heteroskedatisitas}

Tujuan uji normalitas untuk mengetahui apakah data terdistribusi normal atau tidak. Untuk menguji normalitas digunakan Jarque Bera (JB) yang dilakukan terhadap data residual model regresi, dengan ketentuan: a) Jika tingkat signifikansinya $>0,05$, maka data normal; dan b) Jika tingkat signifikansinya $<0,05$, maka data tidak normal.

Uji heteroskedatisitas bertujuan untuk menguji terjadi/tidak ketidaksamaan varian dan residual dalam model regresi. penelitian menggunakan diagram pancar (scatter plot), jika titik-titik tersebut tersebar acak maka tidak terdapat heteroskedastisitas.

Model analisis regresi linier sederhana digunakan untuk menguji pengaruh kualitas pelaksanaan GCG (X) terhadap variabel tingkat pengembalian $\left(\mathrm{Y}_{1}\right)$ dan risiko pembiayaan $\left(\mathrm{Y}_{2}\right)$ dengan langkah:

1. Menguji pengaruh kualitas pelaksanaan GCG terhadap tingkat pengembalian dengan persamaan sebagai berikut:

$\mathrm{Y}_{1}=\beta_{0}+\beta_{1} \mathrm{X}+\mathrm{e}$

Di mana :

$\mathrm{Y}_{1}=\mathrm{ROA}$;

$\mathrm{X}=$ Kualitas pelaksanaan GCG;

$\beta_{0}=$ Konstanta (intersep); dan

$\beta_{1}=$ Koefisien kemiringan (slope)

2. Menguji pengaruh kualitas pelaksanaan GCG terhadap risiko pembiayaan dengan persamaan sebagai berikut:

$\mathrm{Y}_{2}=\beta_{0}+\beta_{2} \mathrm{X}+\mathrm{e}$ 
Di mana:

$\mathrm{Y}_{2}=\mathrm{NPF}$

$\mathrm{X}=$ Kualitas pelaksanaan GCG;

$\beta_{0}=$ Konstanta (intersep); dan

$\beta_{2}=$ Koefisien kemiringan (slope)

\section{Uji-t (t-test)}

Uji t digunakan untuk menguji signifikansi pengaruh kualitas penerapan GCG terhadap tingkat pengembalian dan risiko pembiayaan bank syariah di Indonesia secara parsial. Uji t ini digunakan untuk menguji hipotesis $\mathrm{H}_{1}$ dan $\mathrm{H}_{2}$.

\section{Hasil dan pembahasan}

Sesuai metode purposive sampling terpilih sebanyak 11 Bank Umum Syariah (BUS) dan 1 Unit Usaha Syariah (UUS) yaitu: 1) Bank Muamalat Indonesia; 2) Bank Syariah Mandiri; 3) Bank Mega Syariah; 4) Bank BRI Syariah; 5) Bank Bukopin Syariah; 6) Bank Panin Syariah; 7) Bank Victoria Syariah; 8) Bank BCA Syariah; 9) Bank BJB Syariah; 10) Bank BNI 46 Syariah; 11) Bank Maybank Indonesia Syariah; dan 12) Unit Usaha Syariah Bank DKI.

Untuk mendukung penelitian ini, disajikan data kuantitatif tentang peringkat nilai komposit GCG, ROA dan NPF masing-masing sampel seperti terlihat pada tabel 1 .

Tabel 1

Deskripsi Variabel Penelitian Observasi Awal $(\mathrm{n}=36)$

\begin{tabular}{cccrrrr}
\hline No & Variabel & N & \multicolumn{1}{c}{ Min } & Max & Mean & Standar Deviasi $(\delta)$ \\
\hline 1 & GCG & 36 & 1,15 & 2,53 & 1,79 & 0,37 \\
2 & ROA & 36 & 0,2 & 6,93 & 1,72 & 1,41 \\
3 & NPF & 36 & 0 & 15,4 & 2,36 & 3,49 \\
\hline
\end{tabular}

Sumber: Data Sekunder Diolah, 2016

Untuk keperluan analisis perlu disampaikan juga data kuantitatif tentang nilai rata-rata (mean) kualitas GCG, nilai minimum GCG, dan nilai maksimum GCG seperti yang tardapat pada tabel 2. 
Tabel 2

Data GCG Bank Syariah 2013-2015

\begin{tabular}{llrrrrrr}
\hline \multirow{2}{*}{ No } & \multirow{2}{*}{ Bank Syariah } & \multicolumn{3}{c}{ GCG } & \multicolumn{4}{c}{ Capaian } \\
\cline { 2 - 7 } & & 2015 & 2013 & 2012 & Max & Min & \multicolumn{1}{c}{ Mean } \\
\hline 1 & BMI & 1,15 & 1,3 & 1,4 & 1,4 & 1,15 & 1,28 \\
2 & BSM & 1,68 & 1,6 & 1,35 & 1,68 & 1,35 & 1,532 \\
3 & MIS & 1,6 & 1,83 & 1,88 & 1,88 & 1,6 & 1,758 \\
4 & BRIS & 1,38 & 1,55 & 1,61 & 1,61 & 1,38 & 1,506 \\
5 & BUKOPIN & 1,8 & 1,6 & 1,6 & 1,8 & 1,6 & 1,68 \\
6 & PANIN & 2,2 & 1,95 & 1,35 & 2,2 & 1,35 & 1,81 \\
7 & VICTORIA & 2 & 2,05 & 2,07 & 2,07 & 2 & 2,038 \\
8 & BCAS & 2,1 & 1,9 & 1,8 & 2,1 & 1,8 & 1,94 \\
9 & BJB & 2,48 & 2,5 & 2,53 & 2,53 & 2,48 & 2,504 \\
10 & BNI & 1,63 & 1,68 & 1,25 & 1,68 & 1,25 & 1,498 \\
11 & MAY BANK & 2,4 & 2 & 2,3 & 2,4 & 2 & 2,22 \\
12 & DKI & 1,8 & 1,58 & 1,54 & 1,8 & 1,54 & 1,652 \\
& Max & 2,48 & 2,5 & 2,53 & - & - & $\mathbf{2 , 5 0 4}$ \\
& Min & 1,15 & 1,3 & 1,25 & - & - & $\mathbf{1 , 2 8}$ \\
& Mean & 1,84643 & 1,81 & 1,74714 & - & - & $\mathbf{1 , 8 0 0 1 4}$ \\
& Modus & 1,8 & 1,6 & 1,35 & - & - & - \\
\hline
\end{tabular}

Sumber: Data Sekunder Diolah, 2016

\section{Uji Normalitas dan Heteroskedatisitas}

\section{Uji Normalitas}

Pengujian normalitas diterapkan pada nilai residu dari hasil regresi. Metode yang digunakan Jarque Bera (JB) yang dilakukan terhadap data residual model regresi. Jika nilai sig $>0,05$ maka tidak ada masalah dengan normalitas. Adapun pengujian total sampel data disajikan pada Tabel 3 dan Tabel 4 berikut ini.

Hasil pengujian normalitas data yang tercantum pada tabel 3 dan tabel 4 menunjukkan semua nilai probabilitas Jarque Bera > 0,05, maka uji normalitas menunjukkan bahwa residu terdistribusi normal. 
Pengaruh Kualitas Penerapan Good Corporate Governance (GCG)...

Tabel 3

Hasil Uji Normalitas ROA

\begin{tabular}{|c|c|c|c|c|c|c|c|c|c|c|c|}
\hline & RESID BMI & RESID BSH & RESID HIS & RESIO BRIS & RESID BUL_. & RESID PA... & RESID V... & RESID BC.. & RESIO BN8 & RESID BNI & RESID $M A$. \\
\hline Mean & 8967111 & .2077093 & .2237844 & $-16978+5$ & .21 .17467 & .20 .68438 & -31.28374 & 2831471 & .49 .11831 & .16 .21340 & 3492976 \\
\hline Median & 8.967111 & 20.77093 & .2237844 & .1697815 & .21 .17487 & .2068468 & -31.28374 & .2831471 & .48 .11831 & -16.21340 & .34 .92976 \\
\hline Haximum & 6711509 & .19 .75967 & .17 .09967 & .1394164 & .21 .15967 & .10 .94553 & .28 .23474 & 2684070 & .4730981 & 9.756515 & 30.09973 \\
\hline Minimum & .112192 & 21.78218 & .2665721 & .8001460 & 21.18967 & -30.42472 & .34 .33274 & .2977922 & .4584602 & .2206218 & 39.75978 \\
\hline Std. Dev. & 3185533 & 1.430132 & 6333994 & 4294278 & 0021213 & 137751 & 4311939 & 2071834 & 100028 & 9.11995 & 6.630605 \\
\hline Skewness & $-124 E-15$ & 000000 & $1,19 E-15$ & $8.80 E-16$ & 000000 & $25 E-16$ & 0,00000 & 0,00000 & $146 E-14$ & $424 E-16$ & $1.14 \mathrm{E}-15$ \\
\hline Kartos's & 100000 & 100000 & 1.000000 & 1000000 & 100000 & 1,00000 & 1.00000 & 100000 & 100000 & 100000 & 100000 \\
\hline Jarque-Bera & 0.333333 & 0.353333 & 0353533 & 0333333 & 0.333333 & 0.333333 & 0323533 & 0333333 & 0333333 & 0.333333 & 0.333333 \\
\hline Probability & 0865492 & 0.845492 & 0846452 & 0.846492 & 0.845482 & 0845492 & 0846482 & 0846492 & 0.845482 & 0.845632 & 0846492 \\
\hline & & & & & & & & & & & \\
\hline Sum & .1793422 & .4154185 & 44.75087 & .3395630 & .4234934 & 41.3093 & 6256740 & 5662942 & $\$ 25563$ & 32.42680 & 69.65951 \\
\hline Sum Sq. Dev. & 10.14762 & $20452 \pi$ & 4011872 & 184003 & 0,000450 & 109.7300 & 1859202 & 4292486 & $1.06143 \mathrm{t}$ & 83.17361 & 4665805 \\
\hline & & & & & & & & & & & \\
\hline Observations & 2 & 2 & 2 & 2 & 2 & 2 & 2 & 2 & 2 & 2 & 2 \\
\hline
\end{tabular}

Sumber: Data Sekunder Diolah, 2016

Tabel 4

\section{Hasil Uji Normalitas NPF}

\begin{tabular}{|c|c|c|c|c|c|c|c|c|c|c|c|}
\hline & RESID BMAI & RESID BSH & RESID HIS & AESID BASS & RESIO BU... & RESIO PA.. & RESID V... & RESID BC. & RESID BNB & RESID BNI & RESID MA \\
\hline Mean & .10 .12129 & .1893216 & .24 .56503 & .17 .08499 & -20.43635 & -2834971 & -33.41574 & -3162639 & 4755614 & -1729799 & 40.22977 \\
\hline Median & $-1095 \% 2$ & .2075967 & .564721 & -18.08465 & -1996567 & .3135472 & -33.35274 & .3067972 & 47.41662 & .2053717 & .4130978 \\
\hline Haximum & 724599 & .1294453 & .20 .30967 & .1329164 & -17.4667 & .1404553 & .33 .22474 & .27 .69970 & 4696181 & 9824515 & .3360973 \\
\hline Minimum & -1221964 & 23.09218 & 27.82221 & .19 .86867 & 2389970 & 3964976 & .33 .66873 & 3650975 & 4820981 & .2153218 & .4562990 \\
\hline Std. Dev. & 2586606 & 5314809 & 3996416 & 3402783 & 3245280 & 1306439 & 0.229087 & 4.485682 & 0622638 & 6.491226 & 6.063827 \\
\hline Skewness & 0.523057 & 0.557003 & 0.638929 & 0.497116 & -0259718 & 0.400209 & 0.466979 & -0370450 & 0339153 & 0.609451 & 0.336579 \\
\hline Kurtosis & 150000 & 150000 & 150000 & 150000 & 150000 & 150000 & 150000 & 150000 & 150000 & 1500000 & 1.50000 \\
\hline Jarque Bera & 0.418044 & 0.436376 & 0.486365 & 0,404812 & 0.314717 & 0351334 & 0.390284 & 0349067 & 0338762 & 0.518240 & 0.330568 \\
\hline Probability & 0811377 & 0803974 & 0.784521 & 0816763 & 0854398 & 0.834713 & 0822718 & 0896513 & 0844187 & 0.771731 & 0,844269 \\
\hline Sum & 301236 & 577656 & .7465909 & .51 .8197 & -6130904 & Sर 04912 & 100.2472 & .9487917 & -1426084 & 51 8ख्वखण & .1200293 \\
\hline Sum Sq. Dev. & 1330002 & 56.46008 & 31.92670 & 23.15786 & 2106568 & 3413566 & 0.104962 & 4024090 & 0775355 & 84.27203 & 7353999 \\
\hline Observations & 3 & 3 & 3 & 3 & 3 & 3 & 3 & 3 & 3 & 3 & 3 \\
\hline & & & & & & & & & & & \\
\hline
\end{tabular}

Sumber: Data Sekunder Diolah, 2016

\section{Uji Heteroskedatisitas}

Dalam penelitian ini digunakan diagram pancar (scatter plot), jika titik-titik tersebut tersebar acak maka tidak terdapat heteroskedastisitas. Adapun hasil uji heteroskedastisitas terdapat pada Gambar 1 sampai Gambar 2 berikut ini 


\section{Gambar 1 \\ Diagram Scatter Plot ROA}

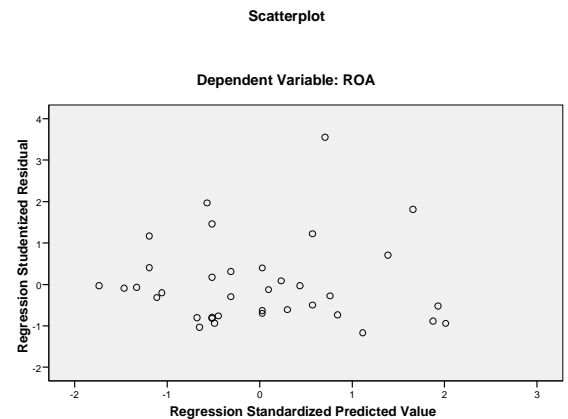

Sumber: Data Sekunder Diolah, 2016

Gambar 2

Diagram Scatter Plot NPF

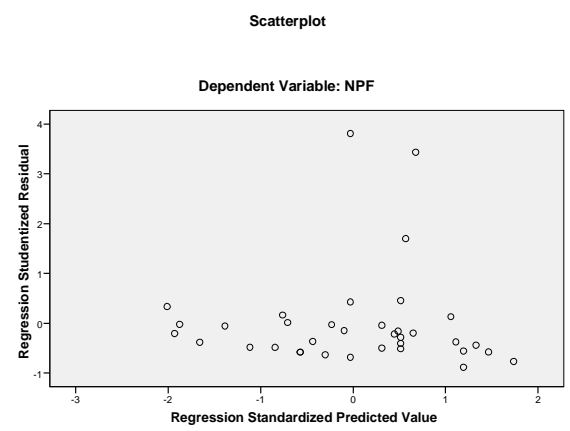

Sumber: Data Sekunder Diolah, 2016

Dengan melihat grafik-grafik scatterplot pada gambar 1 dan gambar 2 di atas terlihat titik-titik menyebar secara acak, tersebar baik di atas maupun di bawah angka 0 pada sumbu Y. Maka dapat diambil kesimpulan bahwa tidak terdapat gejala heteroskedastisitas pada model regresi yang digunakan.

\section{Analisis regresi}

Analisis yang digunakan dalam penelitian ini yaitu regresi linier sederhana. Analisis ini digunakan untuk mengetahui besarnya pengaruh variabel bebas (independent) yaitu kualitas GCG (X) terhadap variabel terikat 
(dependent) yaitu tingkat pengembalian (ROA) dan risiko pembiayaan (NPF). Berdasarkan perhitungan dengan menggunakan program Eviews diperoleh hasil pengujian hipotesis (Tabel 5) sebagai berikut.

Tabel 5

Hasil Pengujian Hipotesis

\begin{tabular}{crr}
\hline Komponen & ROA & NPF \\
\hline Intersep & 1,899547 & 3,033882 \\
GCG & $-0,242962$ & $-0,76788$ \\
R $^{2}$ & 0,734526 & 0,282604 \\
F-hitung & 88,53915 & 13,39364 \\
Sig F-hitung & 0,000000 & 0,000848 \\
Sig t-hitung & 0,4670 & 0,0643 \\
\hline
\end{tabular}

Sumber: Data Sekunder Diolah, 2016

Dari hasil analisis nilai koefisien/intersep setiap variabel dengan program Eviews di atas, dapat diketahui persamaan regresi linier sederhana yang terbentuk.

a. Model 1: $\operatorname{ROA}\left(\mathrm{Y}_{1}\right)=1,899547-0,242962 \mathrm{X}+\mathrm{e}$

b. Model 2: NPF $\left(\mathrm{Y}_{2}\right)=3,033882-0,767880 \mathrm{X}+\mathrm{e}$

Dari pengujian asumsi klasik dapat diasumsikan bahwa data yang ada terdistribusi normal dan tidak terdapat heteroskedasitas, sehingga memenuhi persyaratan untuk melakukan analisis regresi sederhana. Pengujian hipotesis menggunakan Uji t (t-test).

\section{Uji-t (t-test)}

Pada tabel 5 terlihat pengaruh GCG terhadap ROA nilai koefisien regresi (t-hitung) nya sebesar $-0,736084$ dengan tingkat signifikansi sebesar $0,4670$. Hal ini berarti nilai sig t lebih besar dari 0,1 ( $\operatorname{sig} t>0,1)$. Dari hasil uji $t$ ini menunjukkan variabel GCG tidak berpengaruh signifikan terhadap ROA. Hal ini menunjukkan hipotesis $1\left(\mathrm{H}_{1}\right)$ yang menyatakan bahwa kualitas GCG berpengaruh terhadap tingkat pengembalian bank syariah yang diukur dengan earning (ROA) ditolak.

Dari tabel 5 juga menunjukkan nilai koefisien regresi (t-hitung) pengaruh GCG terhadap NPF sebesar -1,911885 dengan tingkat signifikansi 
sebesar 0,0643. Hal ini berarti nilai sig t lebih kecil dari 0,1 ( $\operatorname{sig} \bar{t} 0,1)$. Dari hasil uji $t$ ini menunjukkan variabel GCG berpengaruh signifikan terhadap NPF. Hal ini menunjukkan hipotesis $2\left(\mathrm{H}_{2}\right)$ yang menyatakan kualitas GCG berpengaruh terhadap risiko pembiayaan bank syariah yang diukur dengan kualitas aset (NPF) diterima.

\section{Pengaruh kualitas penerapan GCG terhadap tingkat pengembalian}

Hasil pengujian hipotesis $1\left(\mathrm{H}_{1}\right)$ yang menyatakan bahwa kualitas GCG berpengaruh terhadap tingkat pengembalian bank syariah yang diukur dengan earning (ROA) ditolak, yang berarti bahwa kualitas penerapan GCG tidak berpengaruh terhadap tingkat pengembalian yang diukur dengan return on assets pada bank syariah.

Hasil penelitian ini berbeda dengan hasil penelitian Indah Purnamasari dan Toto Sugiharto S (2013), Anggraeni (2010) dan Eirene (2010). Kualitas penerapan GCG yang tidak berpengaruh terhadap tingkat pengembalian perusahaan (bank) berlawanan dengan teori yang ada.

Secara teoritis penerapan GCG mampu menambah nilai perusahaan yang berakibat positif bagi tingkat pengembalian, yang pada gilirannya akan meningkatkan return. Hal ini mengindikasikan bahwa perusahaan mampu menghasilkan laba bersih yang lebih tinggi dari aktivitas operasionalnya. Peningkatan laba bersih dalam perusahaan akan menjadikan perusahaan tersebut menjadi perusahaan yang sehat, sehingga akan mempengaruhi kesejahteraan pemegang saham dan akan menarik investor lain untuk menanamkan modalnya diperusahaan.

Tingkat pengembalian perusahaan yang ditunjukkan ROA sebagaimana disebutkan oleh FCGI menyebutkan bahwa GCG dapat memudahkan memperoleh modal, dan cost of capital menjadi lebih rendah. Dapat meningkatkan efisiensi, dan berpengaruh baik terhadap kinerja keuangan. Penerapan GCG mampu menambah nilai perusahaan yang berakibat positif bagi kinerja perusahaan yang pada gilirannya akan meningkatkan return.

Hasil penelitian yang menemukan bahwa kualitas penerapan GCG tidak berpengaruh terhadap ROA dapat dikarenakan pengaruh GCG cenderung bersifat jangka panjang sedangkan penerapan GCG pada perbankan syariah di Indonesia secara mandatory baru berlaku efektif sejak tahun 2007 
dan aturan tentang GCG perbakan syriah baru muncul pada tahun 2010 .

Selain hal di atas, faktor lain yang mempengaruhi adalah pelaksanaan GCG belum diterapkan secara masif. Artinya walaupun internal perbankan syariah telah menerapkan GCG dengan baik, lingkungan eksternal belum sepenuhnya menerapkan GCG. Padahal pihak eksternal seperti pemerintah, pengembang, nasabah, mudharib pada pembiayaan mudharabah, mitra pada pembiayaan musyarakah, pengembang dan pada pembiayaan istisna memberikan pengaruh yang besar terhadap perusahaan dan secara langsung berkontribusi terhadap tingkat pengembalian perusahaan.

Apalagi perbankan Syariah dalam sistem pembiayaan mudharabah dan musyarakah mengadopsi model revenue sharing, dimana tingkat pengembalian didasarkan pada kinerja nasabah dan tidak ditentukan dimuka. Maka secara langsung tinggi-rendahnya tingkat pengembalian yang dicapai nasabah akan menentukan tinggi-rendahnya tingkat penegembalian yang diperoleh perbankan syariah.

Reputasi bank yang cukup baik mendorong nasabah untuk tidak ragu dalam menempatkan dananya di bank syariah yang beraset besar. Apabila bank memiliki reputasi yang lebih baik, maka biaya funding bank dengan aset besar akan relatif lebih murah dibandingkan bank dengan aset kecil. Dengan demikian, bank syariah dengan aset besar akan memiliki kesempatan yang lebih besar mendapatkan laba dan menghasilkan imbal hasil modal yang besar bagi pemegang saham.

Praktek tata kelola bank umum syariah yang tidak diiringi dengan praktek tata kelola stakeholders lain tidak akan menjamin kinerja bank. Pada kenyataannya, praktek tata kelola yang diterapkan bank syariah belum diterapkan pada stakeholder di luar bank seperti pemerintah, mudhorib pada pembiayaan mudharabah, mitra pada pembiayaan musyarakah, dan pengembang pada pembiayaan istishna yang sangat berkontribusi terhadap pengembalian bank syariah. Pada produk pembiayaan mudharabah dan musyarakah yang menggunakan bagi hasil, maka tingkat pengembalian yang diterima bank berdasarkan kinerja dan kejujuran mudharib dan mitra. Oleh karena itu, keberhasilan kinerja mudharib dan mitra ini akan menentukan tingkat pengembalian yang akan diterima bank syariah. 
Secara karakteristik, bank syariah membangun diri dengan atribut "Rahmatan lil alamin" dengan prinsip yang menguntungkan kedua belah pihak, bank maupun mitra. Bank umum syariah juga berprinsip amanah dan shiddiq yakni jujur dan dapat dipercaya oleh seluruh pemangku kepentingan. Hal ini menunjukkan bahwa bank umum syariah menonjolkan etika dan keadilan bagi bank dan nasabah. Sehingga, praktek tata kelola menjadi peran penting untuk mendukung prinsip keadilan bagi bank dan nasabah. Bank umum syariah tidak hanya mengedepankan pendapatan (profit oriented) saja melainkan falah oriented. Falah berarti mencari kemakmuran di dunia dan kebahagiaan di akhirat (Antonio 2001: 34). Oleh sebab itu, praktek tata kelola pada bank umum syariah tidak dapat digunakan sebagai penambah nilai.

\section{Pengaruh kualitas penerapan GCG terhadap risiko pembiayaan}

Hasil pengujian hipotesis $2\left(\mathrm{H}_{2}\right)$ diterima. Hasil penelitian ini tidak jauh berbeda dengan hasil penelitian Nagoro (2008) dan Claessens dan Fan (2010). Keberhasilan penerapan GCG dalam mengurangi risiko pembiayaan yang diproksikan dengan NPF sejalan dengan teori yang ada dan sesuai dengan tujuan diterapkannya GCG pada perbankan syariah. Penerapan GCG mampu mengurangi risiko pembiayaan kerena faktor-faktor penerapan GCG yang dikembangkan oleh BI sangat memperhatikan prinsip prudential. Diterapkannya fungsi audit intern dan ekstern sebagai salah satu bentuk penerapan GCG juga turut berkontribusi dalam keberhasilan GCG mengurangi risiko pembiayaan.

Tata kelola yang efektif mendorong sebuah bank untuk menggunakan sumber dayanya dengan lebih efisien dan hati-hati. Praktik tata kelola yang efektif merupakan salah satu prasyarat utama untuk meraih dan menjaga kepercayaan publik terhadap sistem perbankan. Sebaliknya, tata kelola yang buruk dapat meningkatkan kemungkinan kegagalan sebuah bank. Penelitian Tandelilin dkk (2007) membuktikan bahwa tata kelola memiliki pengaruh yang signifikan terhadap manajemen risiko. Selain itu, penelitian Dhaniel Syam dan Taufik Najda (2012) membuktikan bahwa kualitas penerapan tata kelola berpengaruh terhadap risiko pembiayaan. Dengan demikian dapat disimpulkan bahwa penerapan tata kelola dapat mengurangi risiko memiliki pengaruh terhadap risiko suatu bank. 
Pada skema pembiayaan, bank syariah akan bertindak sebagai penjual, sementara nasabah akan menjadi pembeli murabahah. Ditinjau dari berbagai macam produk pembiayaan, profil nasabah dan jenis objek yang dibiayai, akan berpengaruh pada profil risiko pembiayaan. Dari sisi produk pembiayaan, ada produk pembiayaan dengan akad Murabahah, Salam, Istishna, Ijarah, Mudharabah serta Musyarakah. Pembiayaan yang berakad Murabahah dan Ijarah memiliki risiko pembiayaan yang relatif lebih kecil dengan produk pembiayaan lainnya. Hal ini dikarenakan murabahah dan ijarah merupakan pembiayaan yang memberikan marjin hasil tetap (flat) bagi bank umum syariah.

Dari sisi persyaratan pengajuan pembiayaan, pengajuan pembiayaan pada bank umum syariah oleh calon nasabah lebih kompleks dibandingkan dengan mengajukan pada bank konvensional. Selain persyaratan administratif, bank juga mengamati aspek skill dan reputasi. Sementara untuk objek yang akan dibiayai haruslah tidak mengandung gharar, masyir, zalim, riswah apalagi objek haram termasuk sektor non-riil. Hal ini untuk memastikan bahwa bank umum syariah selalu menerapkan prinsip syariah dalam setiap transaksinya, sehingga risiko pembiayaan dapat terjaga.

Secara keseluruhan, komponen tata kelola bank umum syariah yang dikembangkan Bank Indonesia sangat memperhatikan prinsip kehati-hatian (prudent) baik di aspek prinsip syariah maupun pada manajemen risiko. Mulai dari pembentukan Komite Pemantau Risiko yang berada di bawah naungan Dewan Komisaris yang bertugas untuk mengevaluasi tentang kebijakan manajemen risiko, adanya unit kerja khusus di bidang Manajemen Risiko di bawah naungan Direksi yakni Satuan Kerja Manajemen Risiko, adanya Direktur Kepatuhan yang menangani fungsi kepatuhan dengan pembentukan Satuan Kerja khusus di bidang Kepatuhan, hingga pengawasan atas produk dan jasa bank oleh Dewan Pengawas Syariah yang didukung oleh Majelis Ulama Indonesia dan Dewan Syariah Nasional. Dengan demikian, adanya penerapan manajemen risiko pada praktek tata kelola inilah yang mampu menurunkan risiko pembiayaan bank syariah

Non Performing Financing (NPF) menunjukan kemampuan manajemen bank dalam mengelola pembiayaan bermasalah yang diberikan oleh bank. Semakin tinggi rasio ini maka semakin buruk kualitas kredit bank yang menyebabkan kredit bermasalah semakin besar. Hal ini memeperbesar 
kemungkinan kondisi keuangan bank sedang bermasalah (Pratiwi, 2012). Pembiayaan bermasalah adalah pembiayaan dengan kualitas kurang lancar, diragukan dan macet (Almilia, 2005).

Non performing finance (NPF) akan berdampak pada menurunnya tingkat bagi hasil yang dibagikan pada pemilik dana. Hubungan antara bank dan nasabah didasarkan pada dua unsur yang saling terkait, yaitu hukum dan kepercayaan. Suatu bank hanya dapat melakukan kegiatan dan mengembangkan usahanya apabila nasabah percaya untuk menempatkan uangnya. Kemudian setelah menghimpun dana dari masyarakat dalam bentuk simpanan, bank kemudian menyalurkan kembali kepada masyarakat dalam rangka meningkatkan taraf hidup masyarakat (Rahmawulan, 2008). Kredit macet dalam jumlah besar yang relatif besar atau bahkan informasi yang tidak benar mengenai kredit macet yang dialami bank tertentu, jika tidak segera diambil langkah penanggulangan, maka akan menimbulkan kegelisahan pada nasabah bank yang bersangkutan dan memungkinkan terjadinya rush (Joyosumarto dalam Soebagia, 2005).

Berdasarkan Peraturan Bank Indonesia No. 6/9/PBI/2004 yang dimaksud dengan Non Performing Finance (NPF) adalah kredit dengan kualitas kurang lancar, diragukan, dan macet berdasarkan ketentuan Bank Indonesia. Non Performing Finance (NPF) mencerminkan risiko kredit. Semakin kecil Non Performing Finance (NPF), maka semakin kecil pula risiko kredit yang ditanggung oleh pihak bank, sehingga semakin jauh bank tersebut dari kebangkrutan. Agar nilai bank terhadap rasio ini baik, Bank Indonesia menetapkan kriteria rasio NPF net dibawah 5\% (Ayuningrum, 2011). Dengan kata lain NPF merupakan tingkat kredit macet pada bank tersebut. Apabila tingkat NPF tinggi, maka bank tersebut akan mengalami kerugian yang diakibatkan tingkat pengembalian kredit macet, yang bisa berakibat pada kebangkrutan, sebaliknya semakin rendah NPF maka bank tersebut akan semakin mengalami keuntungan, yang berarti bank pada kondisi sehat.

\section{Penutup}

Kualitas penerapan Good Corporate Governance (GCG) tidak berpengaruh terhadap tingkat pengembalian bank syariah yang diukur dengan rentabilitas (ROA). Belum optimalnya kontribusi GCG terhadap tingkat 
pengembalian bank syariah disebabkan GCG belum diterapkan secara masif.

Kualitas penerapan GCG berpengaruh negatif dan signifikan terhadap risiko pembiayaan bank syariah yang diukur dengan kualitas asset (NPF). Hal ini dapat dimungkinkan karena perbankan syariah pernah mengalami kemerosotan dengan perolehan presentase NPF yang cukup tinggi, sehingga risiko pembiayaan bank syariah perusahaan tinggi dan kualitas asset yang dimiliki kurang bagus. Faktor yang lain dapat karena masa penerapan GCG yang masih pendek. Padahal pengaruh GCG cenderung bersifat jangka panjang.

Hasil penelitian pengaruh GCG terhadap kinerja keuangan masih belum konsisten, untuk itu diperlukan penelitian yang lebih mendalam dengan menambah variabel-variabel independen lain yang secara teoritis berpengaruh terhadap kinerja keuangan. Memperbanyak jumlah bank syariah yang dijadikan sampel penelitian dan mengambil periode penelitian yang lebih panjang untuk menyesuaikan dengan karakteristik GCG yang bersifat jangka panjang

Keterbatasan penelitian ini hanya menggunakan data sekunder yaitu laporan publikasi bank. Diharapkan penelitian mendatang dapat menjangkau aspek manajemen bank seperti yang dilakukan oleh Bank Indonesia dalam melakukan penilaian kesehatan bank secara CAMEL Rating Sistem.

\section{Daftar pustaka}

Bhojraj S dan P. Sengupta, Effect of Corporate Governance on Bond Rating and Yields: The Role of Institutional Investors and Outside Directors, 2003. www.ssm.com. Diakses pada tanggal 14 Juni 2016.

Bidabad, Bijan, dan Mahmoud Allahyarifard, Asset and liability Management in Islamic Banking. Paper prepared to be presented 3rd International Conference on Islamic banking and finance (Karachi, Pakistan, 2425 March, 2008), 2010. http://www.bidabad.com/doc/almenglish.pdf. Diakses pada tanggal 14 Juni 2016.

Claessens, Stjin, dan J. P. H. Fan,"Corporate Governance in Asia: a Survey," International Review of Finance, vol. 3 (2), 2002.

Eisenhardt, Kathleem , Agency Theory: An Assesment and Review, Academy of Management Review, 14, 1989. http://cyber.unissula.ac.id/ journal/dosen/publikasi/211406018/311 camels.pdf. Diakses pada tanggal 15 Juni 2016. 
Guthrie, J, dan L.D. Parker,"Corporate social reporting: A Rebuttal of Legitimacy Theory," Accounting and Business Research, vol. 19 No. 76, 2006.

Ismail, Rifki, Islamic Banking Characteristics Economic Condition and Liquidity Risk Problem (Indonesia Case: 2001-2007),2010, http:// www.docstoc.com/docs/9464086/islamic-banking-and-liquidityrisk-problem. Diakses pada tanggal 15 Juni 2016.

Kaiguo, Zhou dan M.C.S. Wong,"The Determinans of Net Interest Margins of Commercial Banks in Mainland China." Journal Emerging Market Finance and Trade. Vol. 44, No. 5, 2008.

Mathuva,"Capital Adequency, Cost Income Ratio and the Performance of Commercial Banks : The Kenyan Scenario." The International Journal of Applied Economics and Finance. Vol. 3, No. 2, 2009.

Nagoro, Chandra Bowo, Penerapan Prinsip-Prinsip GCG Pada Bank BUMN (Studi Kasus Pada Bank BRI), MMH, vol. 37 (1), 2008.

Nur Farida, Yusriati dkk, "Pengaruh Penerapan CG Terhadap Timbulnya Earnings Management Dalam Menilai Kinerja Keuangan Pada Perbankan Syariah Indonesia," Jurnal Bisnis Dan Akuntansi Unsoed Purwokerto Vol. 12, No. 2, Agustus 2010.

Pieris, John, dan Nizam Jim Wirtawan, Etika Bisnis dan Good Corporate Governance, Edisi pertama, Jakarta: Pelangi Cendikia, 2007.

Purnamasari, Indah, dan Toto Sugiharto S, "Pengaruh penerapan GCG terhadap kinerja keuangan perbankan umum yang diukur dengan menggunakan BOPO, CAR, LDR, ROA dan ROE," Jurnal Akuntansi Universitas Gunadarma.http:// repository.gunadarma.ac.id/bitstream/123456789/5630/1/ JURNAL\%201.pdf. Diakses pada tanggal 20 Juni 2016.

Samad, Abdus, dan M. Kabir Hasan, The Performance of Malaysian Islamic Bank during 1984-1997: An Exploratory Study, International Journal of Islamic Financial Services Vol. 1 No.3, 2010. http:// www.nzibo.com/IB2/art1.pdf. Diakses pada tanggal 10 Juni 2016.

Tarawneh, Medhat, "A Comparison Of Financial Performance in the Banking Sector : SomeEvidence from Omani Commercial Banks." International Research Journal of Financeand Economics. http:// www.eurojournals.com/finance.htm. Diakses pada tanggal 15 Juni 2016.

Tondowidjojo, Fenny, dan Anna Purwaningsih, "Manfaat Perubahan Rasio Keuangan Dalam Memprediksi Perubahan Laba: Studi Empiris Pada Perusahaan Perbankan Yang Terdaftar Di Bursa Efek Jakarta”, Modus, Vol. 19, No. 2, 2007. 
Widiyanti, Novi Wulandari,"Corporate Governance dalam Pandangan Islam: Sebuah Konsep Altertantif dalam Penerapan Good Corporate Governance," Jurnal Akuntansi Universitas Jember, 7 (2): 2009.

Wijaya, Tony, "Kontribusi Rasio Keuangan Terhadap Perubahan Laba Perbankan Di Bursa Efek Surabaya". Modus, Vol. 19, No. 2, 2007. 